\title{
Colds and flu - an overview of the management
}

\author{
Halima Ismail, ${ }^{1}$ Natalie Schellack ${ }^{2 *}$ \\ 'Academic Intern, School of Pharmacy, Faculty of Health Sciences, Sefako Makgatho Health Sciences University \\ ${ }^{2}$ Associate Professor, School of Pharmacy, Faculty of Health Sciences, Sefako Makgatho Health Sciences University \\ *Corresponding author, email: natalie.schellack@smu.ac.za
}

\begin{abstract}
The common cold and flu are two very different viruses that share very similar symptoms. The common cold is a self-limiting upper respiratory tract infection and it is caused by the rhinovirus, coronavirus or the adenovirus. It usually resolves within 7-10 days. The flu is caused by the influenza virus and usually presents with headaches, myalgia, fever and body aches. There is no place for antibiotic usage in colds and flu and there is no clinical evidence which suggests that using antibiotics alters the course of the disease or prevents secondary infection. Treatment is mainly symptomatic and includes many over the counter medicines, antivirals and herbal treatment.
\end{abstract}

Keywords: colds, flu, rhinovirus, coronavirus, adenovirus, influenza, upper respiratory tract infections, herbal medicine, antivirals, over-the-counter medicine

\section{Introduction}

The common cold, otherwise known as a self-limiting upper respiratory tract infection, is caused by the rhinovirus, coronavirus or the adenovirus'. Symptoms like sneezing, nasal congestion, coughing, sore throat and a low grade fever are often experienced during the winter season ${ }^{2}$. A person may be contagious after being infected with the virus, but before they present with symptoms, and until after all the symptoms have subsided $^{3}$. The viruses in question are airborne and spread quickly via hand-to-hand contact, or via the inhalation of airborne droplets from sneezing and coughing'.

After the virus enters the nasal cavity it damages the ciliated cells resulting in the release of inflammatory mediators and causing inflammation of the nasal tissue lining'. The increase in permeability of the capillary cell walls results in oedema. Oedema is responsible for symptoms like sneezing and nasal congestion ${ }^{1,3}$. A postnasal drip may develop and is responsible for spreading the virus, which leads to a sore throat and coughing'.

Common colds are self-limiting and resolve within 7-10 days without the use of antibiotics. However, some people may develop a secondary bacterial infection ${ }^{2}$.

The common cold is often confused with the flu. However, the flu is a viral illness that is caused by the influenza virus and has a high mortality and hospitalization rate ${ }^{4}$. Influenza can occur all year round but is seen more from May through winter. Due to the
Hand-to-hand contact: Self-infection by touching a person or object that is infected with the virus.

Droplet transmisssion: Inhalation of airborne droplets.

Close contact with infected persons: Infection by disposition of large air droplets from sneezing.

Figure 1: Transmission of viruses that cause colds ${ }^{2}$

constant evolution of the influenza strains there a higher fatality rate associated with the virus ${ }^{1}$.

The influenza virus is transmitted via air droplets when a person comes into close contact with an infected person or via selfinfection when a person comes into direct contact with an infected person or object ${ }^{5}$.

Table 1: Types of influenza strains and their differences ${ }^{1}$.

\begin{tabular}{lll}
\hline Virus Strain: & Influenza A & Influenza B \\
\hline $\begin{array}{l}\text { Who can become } \\
\text { infected: }\end{array}$ & Animals and Humans & Humans \\
$\begin{array}{l}\text { Severity of } \\
\text { infection: }\end{array}$ & $\begin{array}{l}\text { Causes pandemics, } \\
\text { like swine flu and } \\
\text { bird flu. }\end{array}$ & $\begin{array}{l}\text { Less severe than } \\
\text { Influenza A. }\end{array}$ \\
\hline
\end{tabular}

A rapid onset of fever, headaches, myalgia, body aches and pains, sore throat and rhinitis (runny nose) are associated with 
the flu. These symptoms generally last for 4-5 days and then disappear, however a person may experience coughing and malaise for more than 14 days $^{1,2}$. Influenza-like illness (ILI) is an acute respiratory infection that presents with a fever greater than $38^{\circ} \mathrm{C}$, coughing or pharyngitis. The diagnosis of influenza-like illness is rarely based on the patient's clinical picture. Laboratory diagnosis usually includes ${ }^{6}$ :

- Virus isolation in cell culture

- A polymerase chain reaction (PCR) test

- Antigen detection.

\section{Management of common colds and flu}

Pharmacotherapy is directed at alleviating associated symptoms. Antibiotics are often prescribed erroneously, and in the absence of a secondary bacterial infection. Antibiotics should only be administered when a bacterial infection has been identified, and should not be used as a preventative measure. The following measures can be used to either prevent or treat the symptoms of a common cold and the flu (each of these recommendations will be discussed separately) ${ }^{1,5}$ :

- A flu vaccine is recommended by the Centers for Disease Control and Prevention (CDC), in the United States of America, as a preventative measure against the acquisition of the influenza virus

- Selected over-the-counter (OTC) products contain a combination of active ingredients which help with symptomatic relief

- Drinking plenty of fluids, especially water: Water has been shown to be the best fluid with which to lubricate the mucous membranes

- Vitamins and minerals, e.g. vitamin C and zinc sulphate

- Antiviral drugs, e.g. neuraminidase inhibitors (zanamivir and oseltamivir), as well as $\mathrm{N}$-methyl $\mathrm{D}$-aspartate receptor antagonists (amantadine and rimantadine)

- Other, such as orally-inhaled anticholinergics, inhaled corticosteroids, herbal solutions and nonsteroidal antiinflammatory drugs (NSAIDs).

\section{Vitamins and Minerals}

The prophylactic use of vitamin $\mathrm{C}$ has been shown to reduce the risk of developing a cold or flu in certain populations, e.g. athletes, with a reduction of approximately $6 \%$ in the disease duration. However, the evidence that supports the use of vitamin $C$ in high dosages to reduce the severity of a cold or flu is lacking and inconclusive.

Zinc may inhibit viral growth, and could possibly reduce the duration of cold symptoms. However, not enough high-quality trials support the routine and high-dosage use of zinc in preventing a cold or flu. Some reports have been lodged with the US Food and Drug Administration (FDA) that nasal preparations containing zinc may cause loss of smell. Zinc may also reduce the absorption of certain antibiotics. Food containing calcium and phosphorus can impair the absorption of zinc ${ }^{7}$.

\section{Importance of Hydration}

Fluid (especially water) helps to lubricate the mucous membranes of patients suffering from the common cold or influenza. However, some literature contradicts this by suggesting that the provision of extra fluid to patients with acute respiratory conditions may cause hyponatraemia and fluid overload, because of antidiuretic hormone. This hormone is released in adults and children with lower respiratory tract infections and causes water reabsorption from the renal collecting duct. The combination of the increased production of the antidiuretic hormone and extra fluid may lead to fluid overload. Research has not clearly illustrated this in upper respiratory infections yet and water hydration still remains of importance in common colds and flu $\mathbf{u}^{1,8,9}$.

\section{Other strategies used to treat the common cold and flu}

Anticholinergic agents, such as inhaled ipratropium bromide, may be used to treat a cough caused by the common cold. Nasal preparations have shown some efficacy in reducing rhinorrhoea and sneezing. Inhaled corticosteroids can be used to reduce the swelling and inflammation of the nasal mucosa, but have not been shown to provide any benefit in patients diagnosed with a common cold ${ }^{1}$.

Conflicting evidence has emerged about the use of nasal irrigations. Nasal irrigations constitute a mechanical intervention. It is not classified as a decongestant and does not improve ciliary function. Studies have shown that nasal preparations that contain a certain preservative, namely benzalkonium chloride, may worsen symptoms and infections. Nasal washes that contain a lot of fluid and minimal salt can be used to remove mucus from the nose, removing bacterial products, and improving sinonasal function. Nasal irrigations can be used prior to the administration of topical therapies to ensure true sinus distribution ${ }^{1,10}$.

There are several different OTC medications that can be used to alleviate pain and fever associated with the common cold and flu. The typical active ingredients are aspirin, paracetamol and caffeine. Aspirin, however, is contraindicated in children who have a viral infection as they are at risk of developing Reye's syndrome ${ }^{1,2}$.

The use of codeine or hydrocodone as a cough suppressant has not been found to be any more beneficial than a placebo'.

Herbal products and supplements include substances like Echinacea, Chinese herbal cold and allergy products, elderberry extracts, Andrographis paniculata, Pelargonium sidoides and Acanthopanax senticosus ${ }^{1,11}$.

Probiotics were more effective than placebo in reducing the number of episodes as well as the rate of episodes of upper respiratory tract infections ${ }^{11}$.

\section{The flu or influenza vaccine}

Influenza vaccines then provoke an immune response to the antigen found on the surfaces of the viruses. Antigenic drift can occur in the viruses, causing resistance to the vaccine ${ }^{12}$. It is for this reason that recommendations are based on the World Health 
Table 2: Herbal products and supplements ${ }^{1,11}$.

\begin{tabular}{|c|c|c|}
\hline Herbal product & Evidence supporting the use of the medicine & Adverse effects \\
\hline Echinacea & $\begin{array}{l}\text { No evidence supports the use of this product in } \\
\text { the treatment of colds and flu. }\end{array}$ & $\begin{array}{l}\text { People who are allergic to Echinacea develop } \\
\text { erythema nodosum, which features tender, red } \\
\text { nodules under the skin }\end{array}$ \\
\hline Chinese herbal cold and allergy products & $\begin{array}{l}\text { No evidence supports the use of this product in } \\
\text { colds and flu }\end{array}$ & $\begin{array}{l}\text { These products also pose the risk of renal } \\
\text { damage and cancer as they contain aristolochic } \\
\text { acid. }\end{array}$ \\
\hline Elderberry extracts & $\begin{array}{l}\text { Some evidence supports the use of these } \\
\text { extracts in shortening the duration of flu } \\
\text { symptoms. } \\
\text { However this has yet to be confirmed by bigger } \\
\text { studies. }\end{array}$ & $\begin{array}{l}\text { These extracts are unsafe when the leaves, stems, } \\
\text { unripe fruit or uncooked fruit is consumed. }\end{array}$ \\
\hline $\begin{array}{l}\text { Pelargonium sidoides (commonly known } \\
\text { as African geranium) and Acanthopanax } \\
\text { senticosus }\end{array}$ & $\begin{array}{l}\text { Literature has confirmed a reduction in the } \\
\text { duration of } 10 \text { different flu symptoms. }\end{array}$ & $\begin{array}{l}\text { There are isolated reports of liver toxicity; } \\
\text { however, no causative relationship has been } \\
\text { linked to the herb itself. }\end{array}$ \\
\hline
\end{tabular}

Organization's accredited regional laboratories, and changes are made to the composition, in terms of strains of influenza every year ${ }^{13,14}$. This is also the reason why the vaccine that is released in September every year in the Northern Hemisphere is not always exactly the same as that released in February in the Southern Hemisphere.

Antibodies usually develop within two weeks of the vaccine being administered. A peak in immunity occurs four to six weeks after vaccination, which then gradually wanes again. It therefore does not convey lasting immunity against the influenza virus. Immunisation reduces the likelihood of the flu developing in healthy adults by approximately $70-90 \%{ }^{14}$. If a family member or house mate has already developed the flu, vaccination of other members, within $36-48$, hours will still provide effective protection against the virus ${ }^{14}$.

Table 3: List of individuals who would require the flu vaccine as a matter of priority ${ }^{1}$.

\begin{tabular}{l|l}
\hline Individuals that require the vaccine as a matter of priority & pregnant women, and women who are planning to fall \\
pregnant during winter & \\
\hline $\begin{array}{l}\text { Patients younger than } 18 \text { years of age on chronic aspirin } \\
\text { therapy }\end{array}$ & $\begin{array}{l}\text { HIV infected patients (CD4 cell count }>100 \text { cells/uL). } \\
\text { Patients who suffer from any other disease which leaves } \\
\text { them immune compromised }\end{array}$ \\
\hline $\begin{array}{l}\text { People who suffer from an underlying medical condition, e.g. } \\
\text { diabetes mellitus, COPD, heart disease }\end{array}$ & $\begin{array}{l}\text { People older than } 65 \text { years of age, or infants between } 6-49 \\
\text { months of age. }\end{array}$ \\
\hline $\begin{array}{l}\text { People staying in old age homes, frail care facilities and } \\
\text { rehabilitation centres }\end{array}$ & $\begin{array}{l}\text { Pealthcare workers who have direct contact with patients on } \\
\text { a daily basis }\end{array}$
\end{tabular}

In the southern hemisphere, it is recommended that the vaccine be given in April; however, it can be given throughout the winter season. Figure 2 below depicts the adverse effects that are associated with the flu vaccine'.

\section{Allergic reactions in people who have an egg allergy}

Flu-like symptoms, which develop with 2-24 hours after vaccination

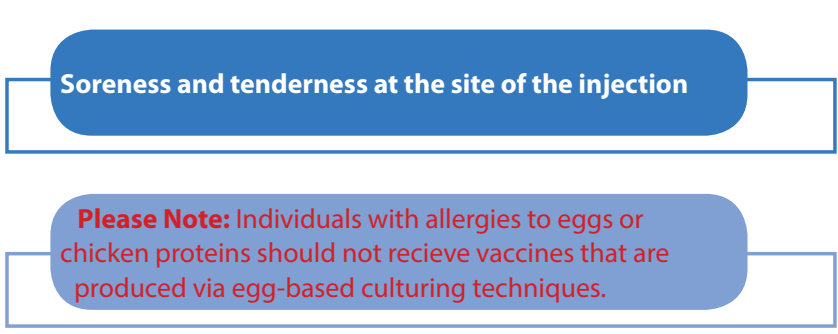

Figure 2: Adverse effects of flu vaccines ${ }^{12,13,14}$.

\section{Combination Products used for common colds and flu}

Antitussive agents (cough suppressants)

Antitussive agents should only be given for a non-productive, dry, irritating cough (refer to Table IV). Care should be taken when giving antitussive agents as the coughing mechanism serves as a protective function of the body. Coughing clears the throat and the lower respiratory tract of foreign particles and mucus. Coughing that occurs as a result of bronchoconstriction and bronchospasm (coughing in asthma and COPD patients) should be treated with bronchodilators. Coughing that is caused by a lower respiratory tract infection should be managed with appropriate antimicrobial agents.

Certain classes of drugs are able to supress the coughing mechanism, such as opioid analgesics and opioid derivatives (codeine phosphate, methadone, etc.) $)^{1,13}$. 
Table 4: Over-the-counter medicine for the treatment of colds and flu $\mathrm{u}^{1,13}$.

\begin{tabular}{|c|c|c|}
\hline Preparation & Active ingredient & Indication \\
\hline \multicolumn{3}{|l|}{ Topical decongestants } \\
\hline Illiadin ${ }^{\circledast}$ & Oxymetazoline $(0.100 \mathrm{mg} / \mathrm{ml})$ & Short-term symptomatic relief of nasal congestion \\
\hline Drixine $^{\circledR}$ & Oxymetazoline $(0.5$ mg/ml) & Short-term symptomatic relief of nasal congestion \\
\hline Nazene ${ }^{\circledast}$ Adult Nasal Metered Spray & Oxymetazoline $(0.5 \mathrm{mg} / \mathrm{ml})$ & Short-term symptomatic relief of nasal congestion \\
\hline Otrivin $^{\oplus}$ & Xylometazoline (1 mg/ml) & Short-term symptomatic relief of nasal congestion \\
\hline Sinutab ${ }^{\oplus}$ Nasal Spray & Xylometazoline (1 mg/ml) & Short-term symptomatic relief of nasal congestion \\
\hline Vibrocil-S ${ }^{\circledast}$ & Phenylephrine and dimethindene $(250 \mathrm{mg} / 100 \mathrm{~g})$ & Short-term symptomatic relief of nasal congestion \\
\hline \multicolumn{3}{|l|}{ Topical Corticosteroids } \\
\hline Avamys $^{\oplus}$ & Fluticasone furoate $(50 \mu \mathrm{g} / \mathrm{spray})$ & Maintenance therapy for allergic rhinitis \\
\hline Beclate Aquanase $^{\circledast}$ & Beclomethasone dipropionate (50 $\mu \mathrm{g} / \mathrm{spray})$ & Maintenance therapy for allergic rhinitis \\
\hline 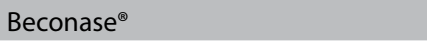 & Beclomethasone dipropionate (50 $\mu \mathrm{g} / \mathrm{spray})$ & Maintenance therapy for allergic rhinitis \\
\hline Clenil $^{\circledR}$ Aq Nasal Spray & Beclomethasone dipropionate (50 $\mu \mathrm{g} / \mathrm{spray})$ & Maintenance therapy for allergic rhinitis \\
\hline Flomist ${ }^{\circledast}$ & Fluticasone propionate (50 $\mathrm{\mu g} / \mathrm{spray})$ & Maintenance therapy for allergic rhinitis \\
\hline Flonase $^{\circledR}$ & Fluticasone propionate (50 $\mu \mathrm{g} / \mathrm{spray})$ & Maintenance therapy for allergic rhinitis \\
\hline Nexomist $^{\oplus}$ & Mometasone furoate $(50 \mu \mathrm{g})$ & Maintenance therapy for allergic rhinitis \\
\hline Rinelon $^{\circledast}$ & Mometasone furoate $(50 \mu \mathrm{g})$ & Maintenance therapy for allergic rhinitis \\
\hline \multicolumn{3}{|c|}{ Topical antihistamines/anti-allergic agents } \\
\hline Rhinolast $^{\circledast}$ & Azelastine (0.14 mg/spray) & Short-term intermittent allergic rhinitis \\
\hline Sinumax Allergy Nasal Spray ${ }^{\circledR}$ & Levocabastine $(0.5 \mathrm{mg} / \mathrm{ml})$ & Short-term intermittent allergic rhinits \\
\hline Vividrin $^{\oplus}$ & Cromoglicic acid (2.6 mg/spray) & Intermittent or persistant allergic rhinitis \\
\hline \multicolumn{3}{|l|}{ Other nasal preparations } \\
\hline Mistabron ${ }^{\oplus}$ & Mesna $(50 \mathrm{mg} / \mathrm{ml})$ & Nasal obstruction owing to thick secretions \\
\hline \multicolumn{3}{|c|}{ Systemic nasal decongestants with antihistamines } \\
\hline Actifed $^{\otimes}$ & Pseudoephedrine $\mathrm{HCl}$ (30 mg) Triprolidine $\mathrm{HCl}$ (1.25 mg) & $\begin{array}{l}\text { Systemic decongestion of nasal mucosa and } \\
\text { sinuses associated with colds and flu }\end{array}$ \\
\hline Betafed Be-Tabs ${ }^{\circledast}$ & Pseudoephedrine $\mathrm{HCl}$ (30 mg) Triprolidine $\mathrm{HCl}$ (1.25 mg) & $\begin{array}{l}\text { Systemic decongestion of nasal mucosa and } \\
\text { sinuses associated with colds and flu }\end{array}$ \\
\hline Demazin Syrup ${ }^{\circledast}$ & $\begin{array}{l}\text { Phenylephrine } \mathrm{HCl}(2.5 \mathrm{mg} / 5 \mathrm{ml}) \text { Chlorpheniramine } \\
(1.25 \mathrm{mg} / 5 \mathrm{ml})\end{array}$ & $\begin{array}{l}\text { Systemic decongestion of nasal mucosa and } \\
\text { sinuses associated with colds and flu }\end{array}$ \\
\hline Demazin $\mathrm{NS}^{\circledR}$ & Pseudoephedrine sulphate (120 mg) Loratidine (5 mg) & $\begin{array}{l}\text { Systemic decongestion of nasal mucosa and } \\
\text { sinuses associated with colds and flu }\end{array}$ \\
\hline \multicolumn{3}{|c|}{ Systemic decongestant and/or analgesic and/or antihistamine combinations } \\
\hline Efferflu $C^{\oplus}$ Cold and Flu & $\begin{array}{l}\text { Paracetamol (500 mg) } \\
\text { Chlorphenamine maleate ( } 2 \mathrm{mg} \text { ) Vitamin C ( } 250 \mathrm{mg})\end{array}$ & Symptomatic relief of colds and flu \\
\hline Benylin ${ }^{\circledR}$ for colds & Pseudoephedrine $\mathrm{HCl}$ (30 mg) Ibuprofen (200 mg) & Symptomatic relief of colds and flu \\
\hline Nurofen ${ }^{\circledast}$ Cold and Flu & Ibuprofen (200 mg) Pseudoephedrine $\mathrm{HCl}$ (30 mg) & Symptomatic relief of colds and flu \\
\hline Sinuclear ${ }^{\circledast}$ & Paracetamol (325 mg) Phenylpropanolamine $\mathrm{HCl}$ (18 mg) & Symptomatic relief of colds and flu \\
\hline Sinugesic ${ }^{\oplus}$ & Paracetamol (500 mg) Pseudoephedrine $\mathrm{HCl}$ (30 mg) & Symptomatic relief of colds and flu \\
\hline Sinumax ${ }^{\circledast}$ & Paracetamol (500 mg) Pseudoephedrine $\mathrm{HCl}$ (30 mg) & Symptomatic relief of colds and flu \\
\hline Sinustat ${ }^{\oplus}$ & Paracetamol (325 mg) Phenylpropanolamine $\mathrm{HCl}$ (18 mg) & Symptomatic relief of colds and flu \\
\hline Sudafed ${ }^{\circledR}$ Sinus Pain & Paracetamol (500 mg) Pseudoephedrine $\mathrm{HCl}(60$ mg) & Symptomatic relief of colds and flu \\
\hline \multicolumn{3}{|l|}{ Cough preparations } \\
\hline \multicolumn{3}{|l|}{ Mucolytic } \\
\hline Solmucol $^{\circledast}$ & N-Acetylcysteine & To reduce viscosity of secretions \\
\hline \multicolumn{3}{|l|}{ Mucatak $^{\circledast}$} \\
\hline \multicolumn{3}{|l|}{ Amuco $200^{\circledR}$} \\
\hline \multicolumn{3}{|l|}{ ACC200 ${ }^{\circledR}$} \\
\hline Betaphlem ${ }^{\circledast}$ & \multirow[t]{5}{*}{ Carbocisteine } & \multirow[t]{5}{*}{ To reduce viscosity of secretions } \\
\hline Bronchette $^{\circledast}$ & & \\
\hline \multirow{3}{*}{$\begin{array}{l}\text { Flemex }^{\circledR} \\
\text { Lessmusec }^{\circledast} \\
\text { Mucospect }^{\circledast}\end{array}$} & & \\
\hline & & \\
\hline & & \\
\hline Bisolvon $^{\circledast}$ & Bromhexine $\mathrm{HCl}$ & To reduce viscosity of secretions \\
\hline \multicolumn{3}{|l|}{ Expectorants } \\
\hline Benylin Wet Cough Menthol $^{\circledR}$ & Guaifenesin & Cough alleviation \\
\hline \multicolumn{3}{|l|}{ Cough suppressants } \\
\hline Benylin ${ }^{\circledR}$ Dry Cough & Dextromethorphan & Symptomatic relief of a non-productive cough \\
\hline \multicolumn{3}{|l|}{ Dilinct $^{\circledR}$ Dry Cough } \\
\hline Nitepax ${ }^{\circledast}$ & Noscapine & \\
\hline Pholtex ${ }^{\oplus}$ Forte & Pholcodine & \\
\hline Pholtex Linctus ${ }^{\circledast}$ & Pholcodine $15 \mathrm{mg} / 10 \mathrm{ml}$ Phenyltoloxamine (10 mg/10 ml) & \\
\hline
\end{tabular}




\section{Antihistamines}

The first-generation antihistamines, such as chlorpheniramine, brompheniramine and promethazine, are used to reduce certain symptoms of a cold, like rhinitis and sneezing. This is due to the anticholinergic effects of these drugs. Some of the firstgeneration antihistamines are also used for their antitussive action and are combined in cold medicines to help patients sleep. Literature has stated that antihistamines used alone are of very little benefit in treating symptoms of the common cold and flu, but they do offer symptomatic relief when used in combination with decongestants and antitussive agents ${ }^{5}$.

Please note: In 2007 promethazine-containing medicines were contraindicated in children under the age of two years ${ }^{15}$.

\section{Expectorants and mucolytic agents}

Expectorants and mucolytic drugs are used to alter the viscosity of mucous and bronchial secretions, thereby making it easier to cough up sputum ${ }^{1,16}$. There are two ways of achieving this through pharmacological action:

- By using expectorants to increase the volume of bronchial secretions and reduce the viscosity of these secretions. Guaiphenesin, sodium citrate and ammonium chloride are examples of expectorants. For obvious reasons, the use of cough mixtures containing an expectorant, as well as an antitussive agent, or combined with an antihistamine, should rather be avoided.

- By using mucolytic agents, which act by altering the structure of mucus, thus resulting in a low mucus viscosity. Examples are: carbocisteine, bromhexine and $\mathrm{N}$-acetylcysteine. Dornase alfa (recombinant human DNase) is used in patients with cystic fibrosis.

Non-pharmacological methods, like maiming a good fluid hydration status and inhaling steam, can also reduce the viscosity of mucous secretions.

\section{Oral decongestants:}

Oral sympathomimetic, systemic decongestants, like pseudoephedrine phenylpropanolamine and phenylephrine are now mainly available in combination in South Africa ${ }^{5}$. Oral decongestants should only be used for a short period of time and as symptomatic relief for acute coryza, as part of flu and influenza. Topical agents are preferred as they have reduced systemic side-effects ${ }^{1}$. Clear warnings should be given to patients about the use of oral decongestants with alcohol or certain drugs like sedatives ${ }^{13,17}$.

\section{Nasal decongestants:}

Nasal congestion, a result of vasodilation and oedema of the nasal mucosa, can be alleviated using alpha-1 adrenergic agonists topically (nasal sprays) or orally. These topical decongestants are actually vasoconstrictors and compared to a placebo have shown a reduction in airway resistance ${ }^{1,5,13,17}$.

\section{Antiviral Agents}

\section{Neuraminidase inhibitors}

Zanamivir and oseltamivir are currently available. These drugs are registered for the prophylaxis of the influenza $A$ and $B$ virus, and should be used within the first 24 hours of the onset of the symptoms. These agents act by inhibiting the enzyme involved in viral replication, neuraminidase. Important information regarding the use of these agents is listed in Figure 3 below ${ }^{1,18}$ :
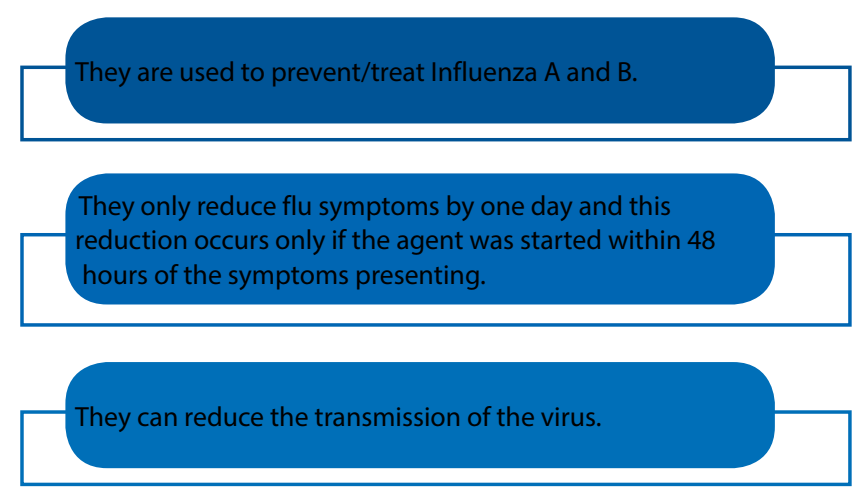

Oseltamivir has been approved in preventing the virus from occurring in patients older than one year.

If used within the first four days of the symptoms presenting, they can prevent complications of the virus.

Their use in avian ('bird') flu has not been fully established.

Oseltamivir should be intitated in indviduals who are at a higher risk of contracting influenza and complications of influenza like immune compromised patients.

Reports of fatal neuropsychiatric conditions have been filed.

Figure 3: important information regarding the use of oseltamivir and zanamivir $^{1,18}$.

Table 5: Important differences between zanamivir and oseltamivir ${ }^{1,18}$.

\begin{tabular}{ll}
\hline Zanamivir & Oseltamivir \\
\hline Administered through an inhaler. & $\begin{array}{l}\text { Available as a suspension and a } \\
\text { capsule. } \\
\text { It has minor side effects like } \\
\text { nausea and vomiting. }\end{array}$ \\
$\begin{array}{l}\text { May provide a challenge to older } \\
\text { patients and patients with a lung } \\
\text { disorder. }\end{array}$ & $\begin{array}{l}\text { Dosage adjustments in patients } \\
\text { with renal impairment. }\end{array}$ \\
\hline
\end{tabular}

\section{$\mathrm{N}$-methyl D-aspartate receptor antagonists}

Amantadine is an antiviral drug that is commonly associated with the treatment of Parkinson's disease. It is however also used in the prevention and treatment of influenza A. Amantadine acts by increasing the amount of dopamine from the nigrostriatal 
pathway and inhibits the reuptake of dopamine by the neurons. Amantadine is currently not recommended for treatment or use as an antiviral agent as there is wide-spread resistance to the drug $^{1,13,18}$.

If the drug is being used for minor sensitive strains the following should be noted:

- Initiation of amantadine should occur within 2 days after contracting influenza $A$ as it may reduce the duration of the disease.

- It cannot be used against influenza B.

- There is no literature which supports the drug preventing complication of influenza A.

\section{Conclusion}

Antibiotics should never be used to treat the common cold or flu, unless there is a secondary bacterial infection. There is insufficient evidence in the literature to supports the use of OTC producrs for the prevention of these viral infections; however, vitamin $C$ and zinc can be used as prophylaxis. Receiving the influenza vaccine may reduce the risk of acquiring seasonal influenza. Treatment is symptomatic; however, the use of many of the OTC medicines is not supported by literature. Certain herbal remedies like $P$. sidoides extract, $A$. paniculata and elderberry may be effective, although a person should always read the safety profile of these remedies first. Codeine and antihistamines may be used in combination therapies to treat coughs and other cold symptoms. Medicines, such as paracetamol and other NSAIDs, may be used to manage pain and fever in adults. Antivirals, such as the neuraminidase inhibitors, can be used in the prevention and treatment of both influenza $A$ and $B$.

\section{References}

1. Schellack, N. and Labuschagne, Q. (2014). Overview and management of colds and flu. South African Pharmacy Journal, 81(6), pp.19-26.

2. Uptodate.com. (2017). The common cold in children: Clinical features and diagnosis. [online] Available at: https://www.uptodate.com/contents/ the-common-cold-in-children-clinical-features-and-diagnosis [Accessed $3 \mathrm{Apr}$. 2017].

3. National Prescribing Centre, (2017). [online] Available at: NHS National Prescribing Centre. Common cold. NHS [homepage on the Internet]. 2006. c2014. Available from: http://www.npc.nhs.uk/merec/infect/commonintro/ resources/ merec_bulletin_vol17_no3_common_cold.pdf [Accessed 3 Apr. 2017].

4. Hermsen ED, Rupp ME. Influenza. Pharmacotherapy: a pathophysiologic approach. In: DiPiro JT, editor. New York: McGraw Hill, 2008; p.1791-1799.

5. Van Schoor, J. (2013). Colds, flu and coughing: a review of over-the-counter cold and flu medicines. South African Family Practice, 55(4), pp.334-336.

6. Perrotta, D., Bella, A., Rizzo, C. and Paolotti, D., 2017. Participatory Online Surveillance as a Supplementary Tool to Sentinel Doctors for Influenza-Like Illness Surveillance in Italy. PloS one, 12(1), p.e0169801.

7. Wright, C.I., 2016. Awareness of'Does Finiflu (Containing Garlic, Onion and Chili) Provide Symptomatic Relief from Cold and Flu?. Current Trends in Nutraceuticals, 1(1), p.6.

8. Guppy MPB, Mickan SM, Del Mar CB. "Drink plenty of fluids": a systematic review of evidence for this recommendation in acute respiratory infections. BMJ. 2004328(7438):499- 500

9. Byber, K., Flatz, A., Norbäck, D., Hitzke, C., Imo, D., Schwenkglenks, M., Puhan, M.A., Dressel, H. and Mutsch, M., 2016. Humidification of indoor air for preventing or reducing dryness symptoms or upper respiratory infections in educational settings and at the workplace. The Cochrane Library.

10. Barham, H.P. and Harvey, R.J., 2015. Nasal saline irrigation: therapeutic or homeopathic. Brazilian journal of otorhinolaryngology, 81(5), pp.457-458.

11. Mousa, H.A.L., 2017. Prevention and Treatment of Influenza, InfluenzaLike Illness, and Common Cold by Herbal, Complementary, and Natural Therapies. Journal of evidence-based complementary \& alternative medicine, 22(1), pp.166-174.

12. Vaccines.gov. (2017). Types of Vaccines | Vaccines.gov. [online] Available at: https://www.vaccines.gov/basics/types/index.html [Accessed 3 Apr. 2017].

13. Rossiter D, editor. South African medicines formulary. 11th ed. Cape Town: Health and Medical Publishing Group; 2014.

14. Simon H, Zieve D. Colds and flu: an in-depth report on the diagnosis, treatment and prevention of colds and flu. University of Maryland Medical Centre [homepage on the Internet]. 2013. c2014. Available from: http://health/medical/ reports/articles/colds-and-the-flu [Accessed 3 Apr. 2017].

15. Fda.gov. (2017). Information for Healthcare Professionals - Promethazine (marketed as Phenergan and generic products). [online] Available at: https://www.fda.gov/ Drugs/DrugSafety/PostmarketDrugSafetyInformationforPatientsandProviders/ ucm126465.htm [Accessed 3 Apr. 2017].

16. Schellack G, editor). Pharmacology in clinical practice: application made easy for nurses and allied health professionals. 2nd ed. Claremont: Juta and Company; 2010.

17. Ryan, D., 2016. How to identify and manage seasonal allergic rhinitis. Journal of Community Nursing, 30(2).

18. Jefferson T, Jones M, Doshi P, Del Mar C. Neuraminidase inhibitors for preventing and treating influenza in healthy adults: systematic review and meta-analysis. BMJ. 2009;339:b5106. 